\title{
粉体バイオコークスの燃焼特性に及ぼすトレファクション処理の影響
}

\section{A Study of Influence of the Torrefaction Processing on Combustion Properties of the Powders Bio-Coke}

\author{
田上奈実*・ファイザビンティモハマドノール**・中 館 朋 江*** \\ 難波邦彦****井田民男* \\ Nami TAGAMI, Faiezah binti Mohd Nor, Tomoe NAKADATE, Kunihiko NAMBA and Tamio IDA
}

(Received March 17. 2016)

\begin{abstract}
There are some trial project that replace pulverized coal with bio-char to target the pulverized coal power plant. These will have to solve a lot of issues. However, an electric energy demand is expected to increase more and more in the future by sustainable energy resources. We developed the solid biomass fuel (hereinafter refer to as Bio-coke:BIC) and studies to use as a replacement for coal coke advance. But, BIC has a few demerit. One of them is that the calorific value for unit quantity decrease because it contains a lot of free water and volatile matters. Torrefaction processing is one of the way how to improve the energy efficiency. In this study, we produced BIC from green tea and improved fixed carbon content ratio by torrefaction processing. And we execute thermal analysis and the combustion experiment using torrefied BIC (hereinafter refer to as T-BIC). The purpose of the use in a pulverized coal power plant, the sample crushed it beforehand. Results are found in the following. (1) In the case of volatile matter content ratio less than about $45 \%$, as volatile matter content ratio is high, gasification time for unit quantity increase. In the case of volatile matter content ratio more than about $45 \%$, gasification time for unit quantity close to constant. (2) In the case of fixed carbon content ratio in more than about $50 \%$, as fixed carbon content ratio is high, char combustion time for unit quantity decrease. In the case of fixed carbon content ratio in less than about $50 \%$, char combustion time for unit quantity close to constant.
\end{abstract}

Key Words: Bio-Coke, Torrefaction, Combustion

\section{1. 緒言}

国内電力供給の約 $30 \%$ を占めている微粉炭火力発電で 用いられる微粉炭然料を粉体バイオチャーで代替する試み は、あるものの多くの課題を抱えている。微粉炭火力発電 には、主として瀝青炭が使用されており、その燃料比（固 定炭素分／揮発分）は $1 \sim 2.5$ 程度である ${ }^{1)} 。$ バイオマス を炭化させたバイオチャーの燃焼比は高く、難燃性である と予測され、多様な混焼技術の開発が期待される。しかし、 新興国の目覚ましい工業化と人口増加により、今後ます ます電力エネルギー需要の拡大が予測される中、持続可能 なエネルギー資源は、国家基盤存立の大きな期待と役割を 担っている。

著者らは、石炭／石炭コークス代替燃料として、植物由 来の固体燃料バイオコークス（以下、BIC と表記する）を
開発し ${ }^{2-5)}$ キュポラあるいは高温ガス化溶融炉での石炭コー クス代替燃料として、さらには、バイオコークス専焼ボイ ラーを開発し、灯油代替として、その実績を積み重ねている。 これまでの固体燃料として利用した BICの燃焼試験結果 から、次のデメリットを有している。(1)原料重量ほぼ 100 \%にて成型が可能であり、原料に含まれる水分も含有して いる特徵がある。従って、BIC を燃焼させると、バイオマ スに含まれる発熱量から水分の蒸発潜熱が差し引かれてし まう。（初期水分值に相当分：重量の約 $10 \%$ 程度）(2)重量 収率がほぼ $100 \%$ なので、単位重量当たりの炭素率が原料 に依存しており、キュポラなどの加炭性などの効果が薄い。 （バイオマスの生化学的組成に依存し、40-55\%程度）こ れらの問題を解決するために、トレファクション (半炭化) 処理がある ${ }^{6-9)}$ 。トレファクション処理は、不活性雲囲気下 で、外部から加温することにより、水分や燃焼に起因しな

*近畿大学バイオコークス研究所（† 577-8502 大阪府東大阪市小若江 3-4-1）

Research Institute of Biocoke, Kindai University (3-4-1 Kowakae, Higashiosaka, Osaka, 577-8502 Japan)

$* *$ 近畿大学 総合理工学研究科（干 577-8502 大阪府東大阪市小若江 3-4-1）

Graduate School of Science and Engineering, Kindai University (3-4-1 Kowakae, Higashiosaka, Osaka, 577-8502 Japan)

***近畿大学バイオコークス研究所（～061-1375 北海道恵庭市南島松 157-1）

Research Institute of Biocoke, Kindai University (157-1 Minami-simamatsu, Eniwa, Hokkaido, 061-1375 Japan)

****大阪府立大学工業高等専門学校（干 572-8572 大阪府寝屋川市幸町 26-12）

Osaka Prefecture University College of Technology (26-12 Saiwaicho, Neyagawa, Osaka, 572-8572 Japan) 
い低沸点揮発性ガス、むしろ吸熱特性を有する成分（フル フラールなど）を気化させることで、単位重量当たりのエ ネルギー密度 (発熱量) を高めることが出来る。

また、BIC は高密度かつ高硬度な性質を有することから、 溶解炉や溶融炉での利用が期待されており、実証試験が進 められている 10),11)。しかし、一方で、石炭火力発電への利 用を目指した研究は未だ少なく、微粉炭火力発電に向けた 取り組みも進んでいない。BIC は高硬度であるために、粉 砕性が悪く、BIC の微粉炭火力発電への利用は、現実的で はないが、トレファクション処理を行うことで、粉砕性が 向上し、利用できる可能性がある。石炭は、他の化石資源 と比較しても、埋蔵量は多く低価格で、安定供給が可能で あり、発電効率向上が進められると共に、今後の日本にお いても、主要な発電方法であると期待され、石炭とバイオ マス燃料の混焼を見据えた研究は、推進するべきところで ある。

このような現状に鑑み、粉体バイオマス燃焼の基礎的な 燃焼挙動を解明することは微粉炭火力発電への適用を議論 する上で、必要なデータベースとなる。

本研究では、(1) BIC 成型で使用する粉体バイオマス（以 下、原料と表記する)、(2) BIC 成型過程で熱と圧力を加え、 高密度固形化した BIC の粉砕物 (以下、BIC powder と表記 する)、(3)トレファクション処理を施した BIC の粉砕物（以 下、トレファクション処理を施した BICを T-BIC、T-BIC の粉砕物を T-BIC powder と表記する）の燃焼挙動の特性を 明らかにすることを目的とする。

\section{2. 実験方法}

\subsection{T-BIC 作製}

\subsubsection{BIC 成型}

Table 1 に BIC の成型条件を示す。原料は、緑茶を用い、 前処理として、378 K に保持した乾燥機で絶乾状態まで乾 燥した。絶乾状態にした原料を粉砕機で粉砕した後、自動 フルイにかけた。次に、所定の水分を原料に与え、初期含 水率の調整を行った。

成型は、Fig.1に示すバッチ式の成型装置を使用した。ま ず、アスペクト比（高さ：直径）がほぼ $2: 1$ になるように、 粒度 $250 \mu \mathrm{m}$ 以下の原料を内径 $20 \mathrm{~mm}$ のシリンダへ一定量 充填し、スペーサで挟み込む。次に、油圧ジャッキで設定 圧力 $21.7 \mathrm{MPa}$ で加圧した状態で、電気管状炉でシリンダを 覆い、設定温度 $443 \mathrm{~K}$ まで加熱した。温度は、シリンダに 設けた測定穴にシース型熱電対を挿入して、測定し、温度 コントローラで制御した。設定温度まで昇温した後、加圧 した状態で 6.25 分保持した。最後に、扇風機を使用して室 温まで空冷した後、BICを取り出した。

2.1.2トレファクション処理

トレファクション処理は、鉄製の加熱ボックスにアルミ ホイルで包んだ BIC を投入し、鉄製のふたをし、空気を遮
Table 1 Producing conditions of BIC.

\begin{tabular}{c|c}
\hline Material & Green tea \\
\hline Particles size $[\mu \mathrm{m}]$ & $250>$ \\
\hline Moisture $[\%]$ & 3 \\
\hline Quantity $[\mathrm{g}]$ & 16 \\
\hline Loading pressure $[\mathrm{MPa}]$ & 21.7 \\
\hline Processing temperature $[\mathrm{K}]$ & 443 \\
\hline Holding time $[\mathrm{min}]$. & 6.25 \\
\hline
\end{tabular}

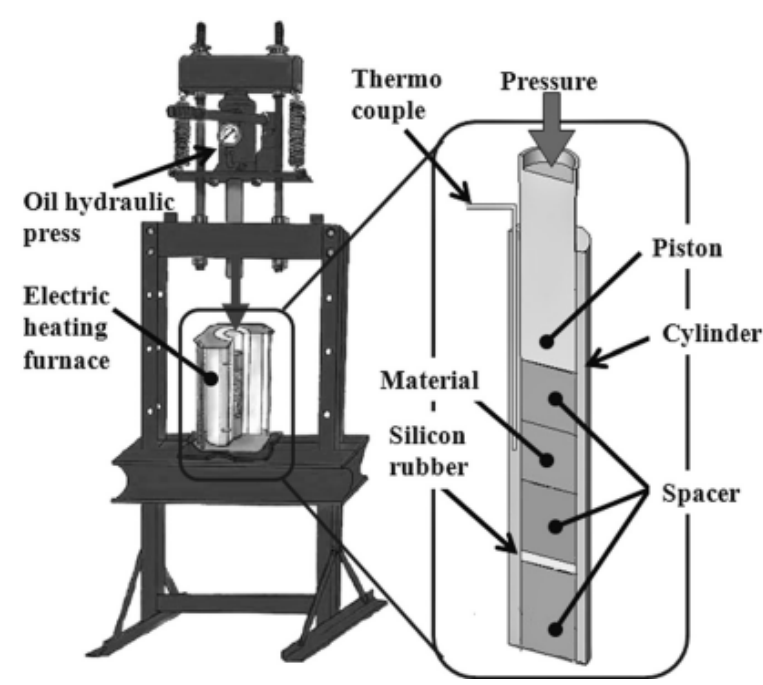

Fig.1 BIC producing device.

断した状態で、ホットプレートにより加熱する。温度は、 熱電対を使用して測定し、ホットプレートの温度を調整す ることで制御した。

緑茶のガス化特性 ${ }^{3)}$ は、示差熱熱重量同時測定より得ら れ、ガス化開始温度は $530 \mathrm{~K}$ 、揮発成分の発熱特性を表す 第 1 ピークは約 $600 \mathrm{~K}$ 付近であり、約 $670 \mathrm{~K}$ 付近から炭素 成分の表面燃焼を表す第 2 発熱領域が開始する。したがっ て、ガス化開始から第 1 発熱ピーク、第 2 発熱開始前温度 までを網羅したトレファイド温度 $\mathrm{Tb}=523 \mathrm{~K} 、 573 \mathrm{~K} 、 623$ K、 $673 \mathrm{~K}$ の 4 パターンとし、各温度まで昇温した後、白煙 がなくなるまで、温度を保持した。室温まで冷却した後、 T-BICの重量を測定し、重量収率を比較した。

\section{2 熱分解特性}

2.1.2で生成した試料の熱分解特性を知るために、示差 熱熱重量同時測定装置（セイコー電子工業、TG/DTA320） を用いて、測定を行った ${ }^{12), 13)}$ 。熱分析条件を Table 2 に示す。 Fig.2は、示差熱熱重量同時測定によって得られる緑茶の 相対重量収率 (TG) 曲線と吸熱・発熱特性 (DTA) 曲線である。 
Table 2 Conditions of thermal analysis.

\begin{tabular}{c|c}
\hline Sample weight $[\mathrm{mg}]$ & 10 \\
\hline Gas flow rate $\left[\mathrm{cm}^{3} / \mathrm{min}.\right]$ & 200 \\
\hline Gas atmosphere & $\mathrm{N}_{2}$, Air \\
\hline Max temperature $[\mathrm{K}]$ & 1073 \\
\hline Heating rate $[\mathrm{K} / \mathrm{min}]$. & 10 \\
\hline
\end{tabular}

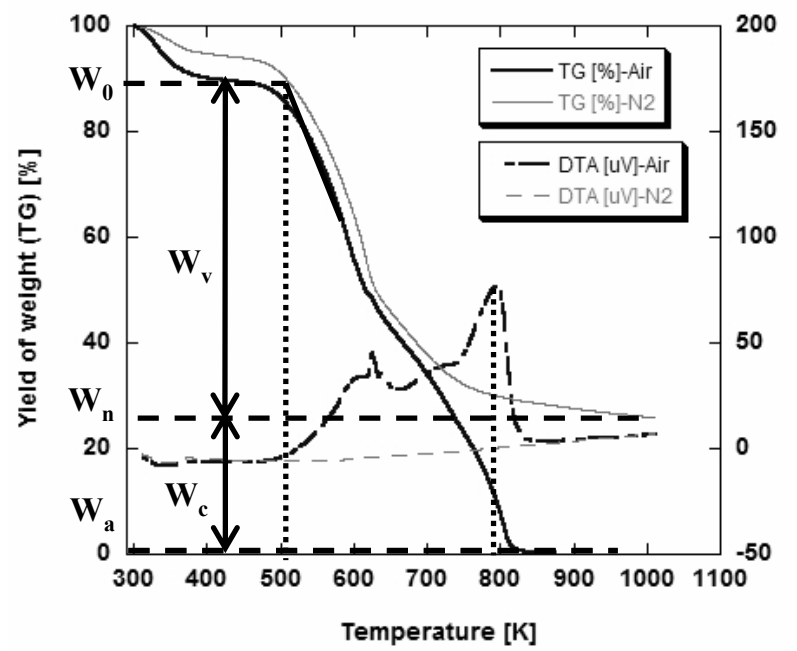

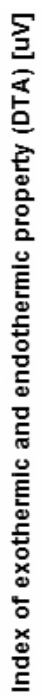

Fig.2 Thermal decomposition curve for green tea, heavy lines correspond to air environment and fine lines correspond to $\mathrm{N}_{2}$ environment.

空気䨌囲気下と窒素䨌囲気下での $\mathrm{TG}$ 曲線から、試料に含 まれる揮発成分率と固定炭素率を得る。まず、約 $380 \mathrm{~K}$ ま では試料中に含まれる水分の蒸発により、重量減少が起こ る。そして、温度上昇に伴って、揮発成分、木タールが熱 分解される。DTA 曲線の $620 \mathrm{~K}$ 付近の第 1 発熱ピークは 木タールの発熱によるものである。そして、800 K 付近で DTA 曲線の発熱の第 2 ピークがある。これは、固定炭素の 燃焼によるものである。第 2 発熱ピークより高温側の TG 曲線に着目すると、窒素䨌囲気下では、重量減少率はほぼ 一定となっている。このときの重量は、熱分解により揮発 成分がガス化した残りであり、固定炭素と死分の和と理解 できる。一方、空気䨌囲気下では、固定炭素の燃焼が起こ るため、重量はさらに減少し、約 $840 \mathrm{~K}$ で一定となり、灰 分のみが残る。約 $420 \mathrm{~K}$ での空気雲囲気下での重量収率 $\mathrm{W}_{0}$ と $1050 \mathrm{~K}$ での窒素雲囲気下での重量収率 $\mathrm{W}_{\mathrm{n}}$ の差を揮発成 分率 $\mathrm{W}_{\mathrm{v}}$ とした。また、 $1050 \mathrm{~K}$ での窒素雲囲気下での重量 収率 $\mathrm{W}_{\mathrm{n}}$ と空気雲囲気下での重量収率 $\mathrm{W}_{\mathrm{a}}$ の差を固定炭素率 $\mathrm{W}_{\mathrm{c}}$ とし、次式で表す。

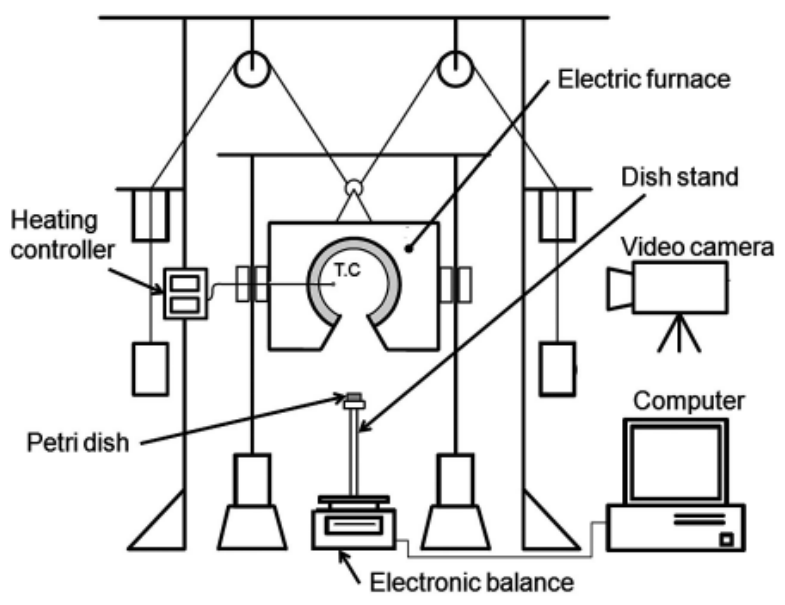

Fig.3 Fall-type electric furnace.

Table 3 Combustion test conditions.

\begin{tabular}{c|c}
\hline Sample & $\begin{array}{c}\text { Raw material (Green tea) } \\
\text { BIC powder } \\
\text { T-BIC powder }\end{array}$ \\
\hline Particles size $[\mu \mathrm{m}]$ & $75>$ \\
\hline Quantity $[\mathrm{g}]$ & 0.25 \\
\hline $\begin{array}{c}\text { Heating temperature } \\
\text { of furnace }[\mathrm{K}]\end{array}$ & $823,873,923$ \\
\hline
\end{tabular}

固定炭素率 $\quad \mathrm{W}_{\mathrm{c}}=\mathrm{W}_{\mathrm{n}}-\mathrm{W}_{\mathrm{a}}$

\section{3 燃焼実験}

燃焼実験装置を Fig.3、燃焼実験条件を Table 3 に示す。 電気炉は落下式であり、電気炉を落下させると、炉底部の 試料の挿入口から試料を投入することが出来る。投入され た試料は、ふく射熱により、加熱される。試料は2.1.2で 生成したT-BIC を粉砕した後、自動フルイにかけ、75 $\mu \mathrm{m}$ 以下にしたものを使用した。電子天秤で $0.25 \mathrm{~g}$ 測定し、石 英シャーレ（\$20 mm、高さ $8 \mathrm{~mm}$ 、厚さ $2 \mathrm{~mm} ）$ に入れた。 試料の表面を平らにならした後、固定台に設置し、電気炉 を落下させ、燃焼過程の観察を行った。加熱炉の設定温度 $\mathrm{Tc}=823 、 873 、 923 \mathrm{~K}$ とした。加熱炉に設けられた石英ガ ラス製の観察空から内部観察可能であり、燃焼過程はこの 観察空の外側からビデオカメラにより、撮影、観察した。 燃焼過程における試料重量は電子天秤（読み取り精度 0.1 $\mathrm{mg}$ ）をコンピュータに接続し、サンプリング周期 3 秒で自 動測定、記録した。

燃焼特性の結果の一例を Fig.4に示す。試料投入後は、 


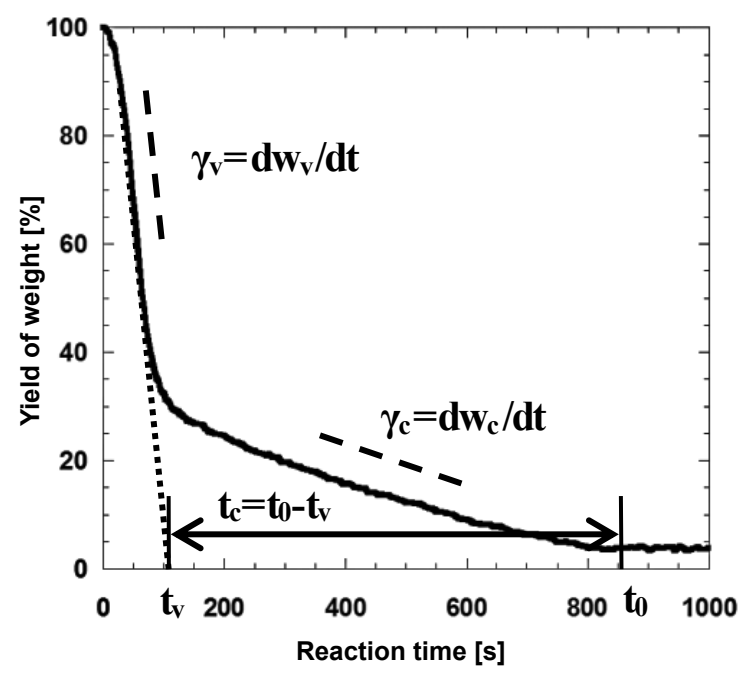

Fig.4 Thermo-gravimetric curves.

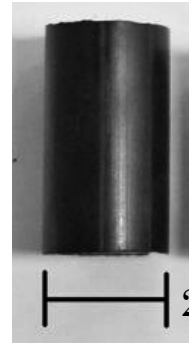

(a)

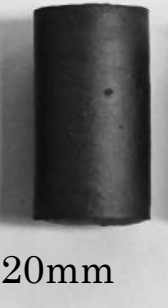

(b)

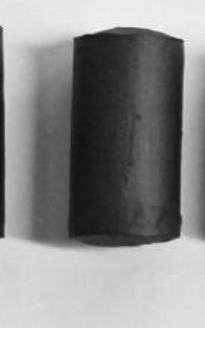

(c)

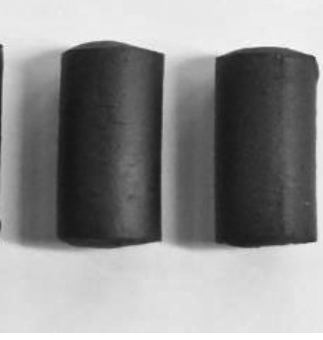

(d)

(e)

Fig.5 T-BIC in the different torrefied temperature:

(a) Pre-torrefaction, (b) $\mathrm{Tb}=523 \mathrm{~K}$, (c) $\mathrm{Tb}=573 \mathrm{~K}$, (d) $\mathrm{Tb}=623 \mathrm{~K}$, (e) $\mathrm{Tb}=673 \mathrm{~K}$.

試料に含まれる水分の蒸発と揮発成分の熱分解が起こる。 揮発成分濃度が燃焼範囲に達すると着火し、有炎燃焼が生 じる。その後、消炎し、重量変化が緩やかなチャー燃焼に 移行する。揮発成分ガス化率 $\mathrm{dw}_{\mathrm{v}}$ 、チャー燃焼による重量 変化率 $\mathrm{dw}_{\mathrm{c}}$ から、単位時間当たりの相対重量ガス化率 $\gamma_{\mathrm{v}}$ 、 単位時間当たりの相対重量チャー燃焼率 $\gamma_{\mathrm{c}}$ を算出し、比較 する。また、全燃焼時間 $\mathrm{t}_{0}$ は、揮発成分のガス化時間とチャー 燃焼時間の和と考えることが出来るが、厳密にガス化時間 とチャー燃焼時間を分割することは困難であるので、ガス 化率 $\gamma_{\mathrm{v}}$ 一定ですべての揮発成分がガス化したと仮定し、経 過時間 $\mathrm{t}$ における揮発成分のガス化率は、(3) 式で表す。こ こで、 c は定数である。

$$
f(t)=-\gamma_{v} t+c
$$

ガス化時間 $t_{v}$ は $f(t)=0$ のとき、

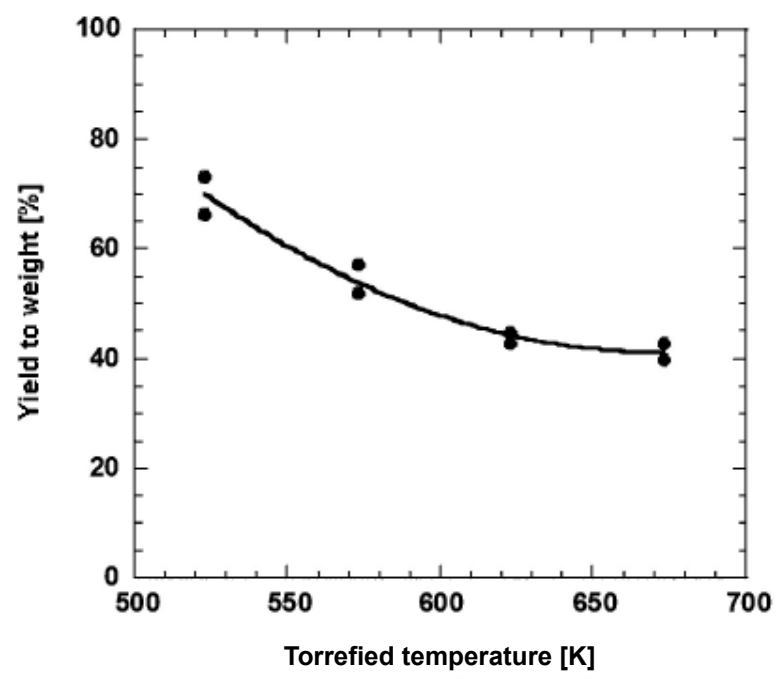

Fig.6 Yield to weight of T- BIC.

$$
\mathrm{t}_{\mathrm{v}}=\mathrm{c} / \gamma_{\mathrm{v}}
$$

である。チャー燃焼時間 $\mathrm{t}_{\mathrm{c}}$ は、ガス化が終了してから、全 燃焼が終了するまで時間と仮定し、(5) 式とした。

$$
\mathrm{t}_{\mathrm{c}}=\mathrm{t}_{0}-\mathrm{t}_{\mathrm{v}}
$$

\section{3. 実験結果および考察}

\subsection{T-BIC 作製}

生成した T-BICの写真を Fig.5 に示す。トレファクショ ン処理温度 $\mathrm{Tb}$ が高くなるにつれて、試料が収縮し、上下 端面が膨らむように変形した ${ }^{9}$ 。またた、Tb が高くなるに従 い、BIC 特有の光沢も見られなくなった。これは、BIC 表 面を覆っていたへミセルロース等の低分子量物質が熱分解 され、ガス化によると推察される。

Fig.6の重量収率に着目すると、Tb が高くになるにつれ、 重量収率は低下していき、673 K 以上で重量収率は、一定 值に推移していることが見て取れる。緑茶のガス化特性に

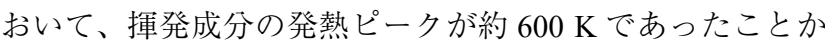
らも、673 K では、揮発成分のほとんどがガス化してしまっ たために、それ以上の重量減少が生じなかったものと考え られる。673 K での重量収率は、約 $40 \%$ であった。

\section{2 熱分解特性}

熱分析の結果を Fig.7、Tb 変化による揮発成分率 $\mathrm{W}_{\mathrm{v}}$ 、固 定炭素率 $\mathrm{W}_{\mathrm{c}}$ を Fig.8 に示す。Tb が高くなるにつれ、 $\mathrm{W}_{\mathrm{v}}$ は 減少し、 $\mathrm{W}_{\mathrm{c}}$ は増加した。 $\mathrm{Tb}$ を下げていくと、 $\mathrm{W}_{\mathrm{v}}$ は増加、 $\mathrm{W}_{\mathrm{c}}$ は減少するが、揮発成分および固定炭素の含有量はバイ オマス原料の固有值があるため、やがて一定となる。トレ ファクション処理により、 $\mathrm{W}_{\mathrm{c}}$ を $25 \%$ から $62 \%$ へ高める 


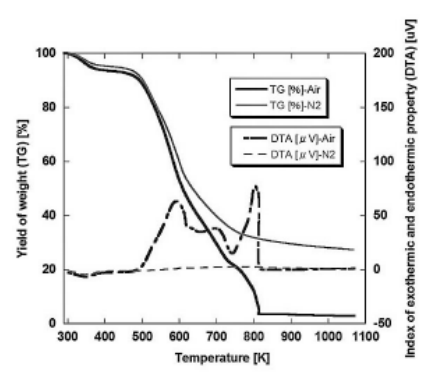

(a) Pre-torrefaction (BIC)

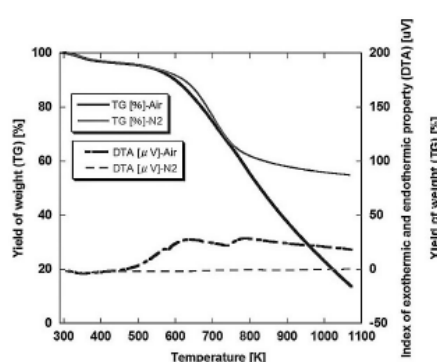

(c) $\mathrm{Tb}=573 \mathrm{~K}$

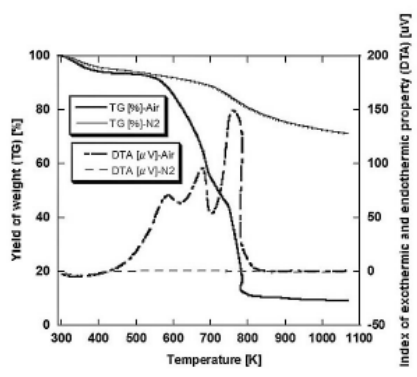

(e) $\mathrm{Tb}=673 \mathrm{~K}$

Fig.7 Thermal decomposition curve of T- BIC (Green tea).

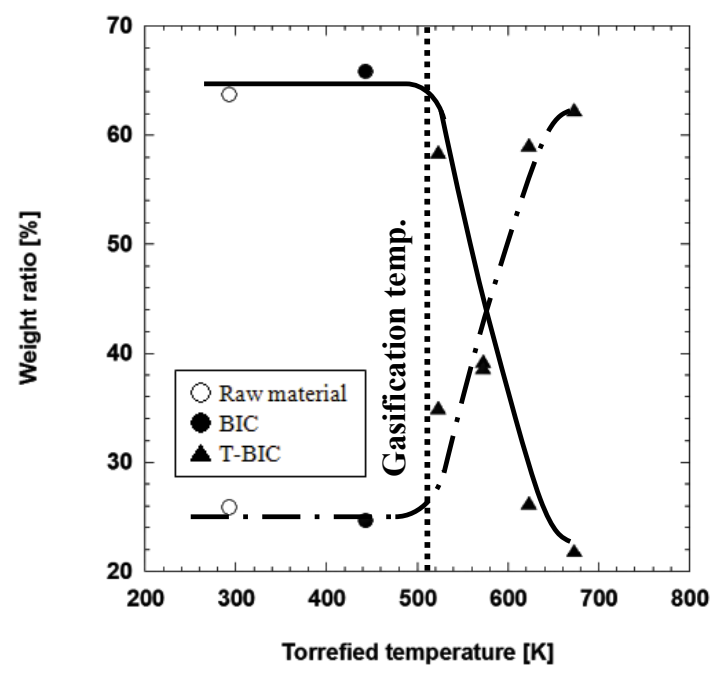

Fig.8 Weight ratio of volatile matter and fixed carbon in difference torrefied temperature: Solid line : Volatile matter, Chain line : Fixed carbon.
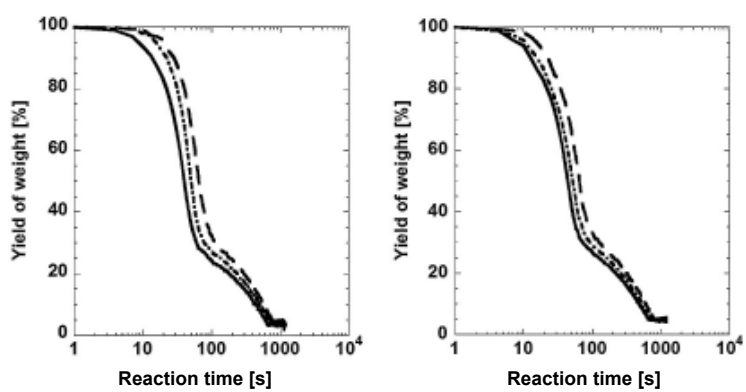

(a) Raw material

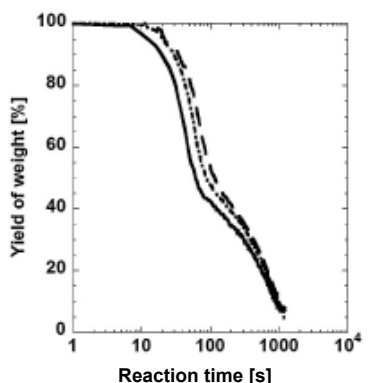

(b) BIC powder

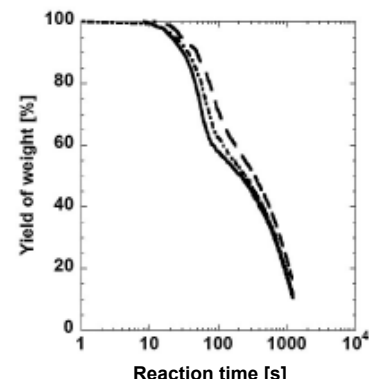

(c) $\mathrm{T}$ - BIC powder $(\mathrm{Tb}=523 \mathrm{~K})$

(d) $\mathrm{T}$ - BIC powder $(\mathrm{Tb}=573 \mathrm{~K})$

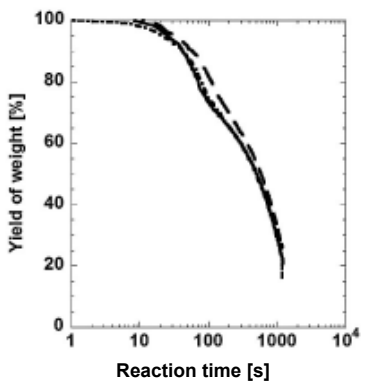

(e) $\mathrm{T}$ - BIC powder $(\mathrm{Tb}=623 \mathrm{~K})$

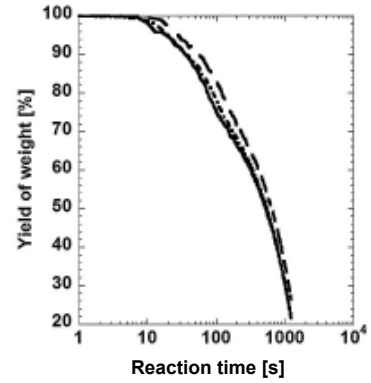

(f) $\mathrm{T}$ - BIC powder $(\mathrm{Tb}=673 \mathrm{~K})$
Fig.9 Thermo-gravimetric curves: Broken line: $\mathrm{Tc}=823 \mathrm{~K}$, Chain line: $\mathrm{Tc}=873 \mathrm{~K}$, Solid line: $\mathrm{Tc}=923 \mathrm{~K}$

\section{ことが出来ることがわかる。}

\section{3 燃焼実験}

炉の設定温度 Tc を変化させた場合における原料、BIC powder、T-BIC powder の燃焼時重量変化の結果を Fig.9に 示す。すべての試料において試料投入の 10 秒後から急激 に重量減少が見られる。この 10 秒間の内に、試料がふく 射熱により与えられた熱量が、揮発成分の揮発潜熱となり、 ガス化が一気に進行したためと考察される。特に、揮発成 分を多く含む原料と BIC powder は、放出される揮発分が多 いため、重量減少が著しい。また、Tcが高いほど、重量減 少が速くなることがわかる。

続いて、燃焼時の揮発成分のガス化域に着目する。 Fig.10に試料投入後、約 $10 \sim 60$ 秒間の Tcに対する単位 時間当たりの相対重量ガス化率 $\gamma_{\mathrm{v}}$ を示す。 $\gamma_{\mathrm{v}}$ は、Tcに対 し直線的に近似でき、その傾きは試料に含有される揮発成 分が多いほど、大きくなることがわかる。この近似線の傾 


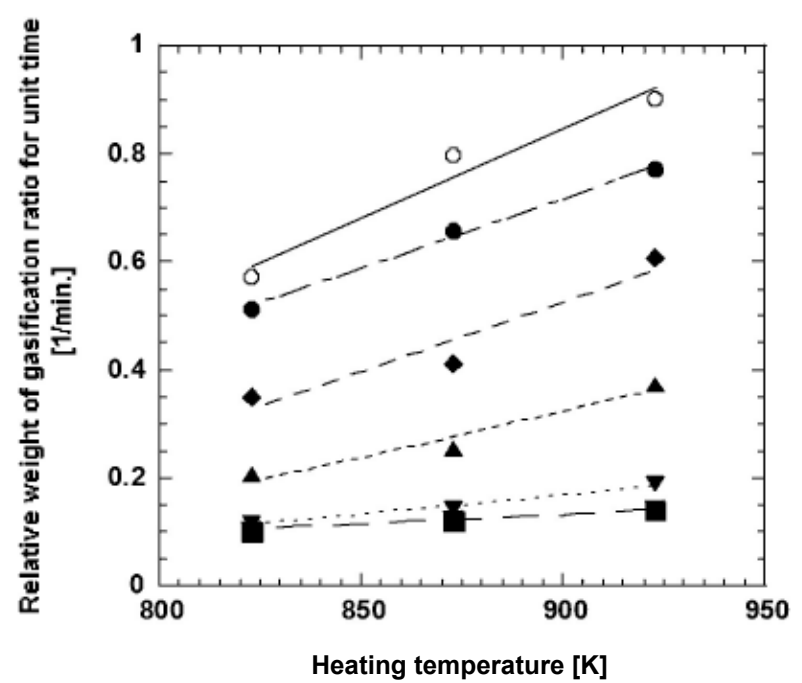

Fig.10 Relative weight of gasification ratio for unit time in different heating temperature: Raw material $(\bigcirc)$, BIC powder $(\mathbf{O})$, T- BIC powder $(\mathrm{Tb}=523 \mathrm{~K})(\boldsymbol{\nabla}), \mathrm{T}-\mathrm{BIC}$ powder $(\mathrm{Tb}=573 \mathrm{~K})(\boldsymbol{\Delta}), \mathrm{T}-$ BIC powder $(\mathrm{Tb}=623 \mathrm{~K})(\boldsymbol{\nabla}), \mathrm{T}-\mathrm{BIC}$ powder $(\mathrm{Tb}=673 \mathrm{~K})(\boldsymbol{\square})$

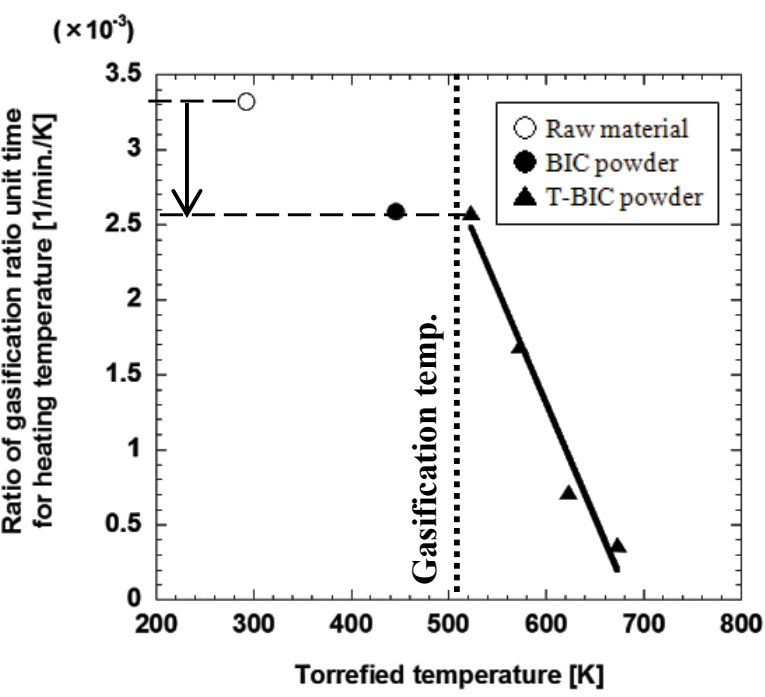

Fig.11 Ratio of gasification rario unit time for heating temperature in different torrefied temperature.

き、すなわち加熱温度 $1 \mathrm{~K}$ 上昇に伴う単位時間当たりのガ ス化率 $\mathrm{m}_{\mathrm{t}}$ と $\mathrm{Tb}$ との相関を Fig. 11 に示す。原料は常温 $293 \mathrm{~K}$ 、 BIC powder は BIC 成型温度 $443 \mathrm{~K}$ を $\mathrm{Tb}$ としてプロットし た。T-BIC powder は Tc と負の相関を持ち、直線的に近似で きることがわかる。揮発成分の含有率が同等の原料と $\mathrm{BIC}$ powderの $\gamma_{\mathrm{v}}$ を比較してみると、BIC powderの方が小さ く、BIC powder の值は $\mathrm{Tb}=523 \mathrm{~K}$ で生成した $\mathrm{T}$-BIC powder と同等のガス化率であった。Fig.12に原料、BIC powder、

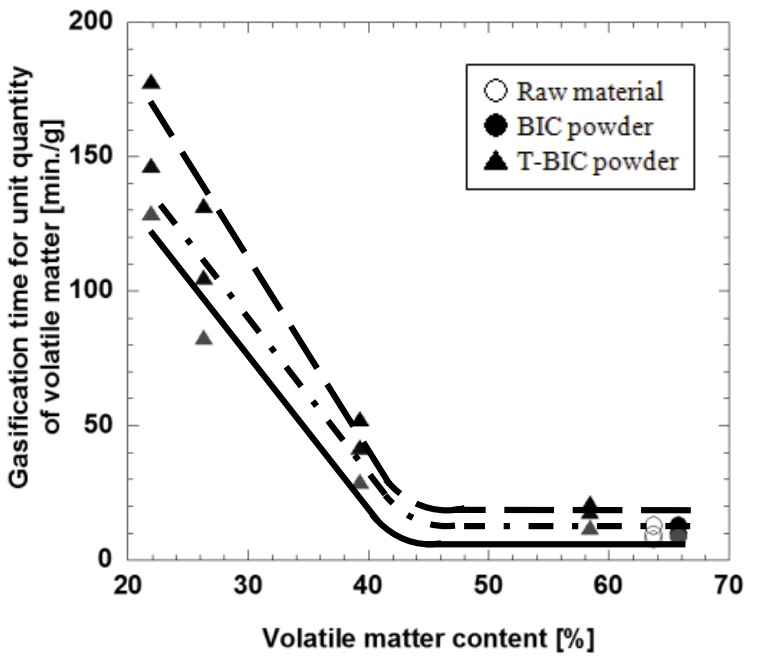

Fig.12 Gasification time for volatile matter content: Broken line $\mathrm{Tc}=823 \mathrm{~K}$, Chain line: $\mathrm{Tc}=873 \mathrm{~K}$, Solid line: $\mathrm{Tc}=923 \mathrm{~K}$

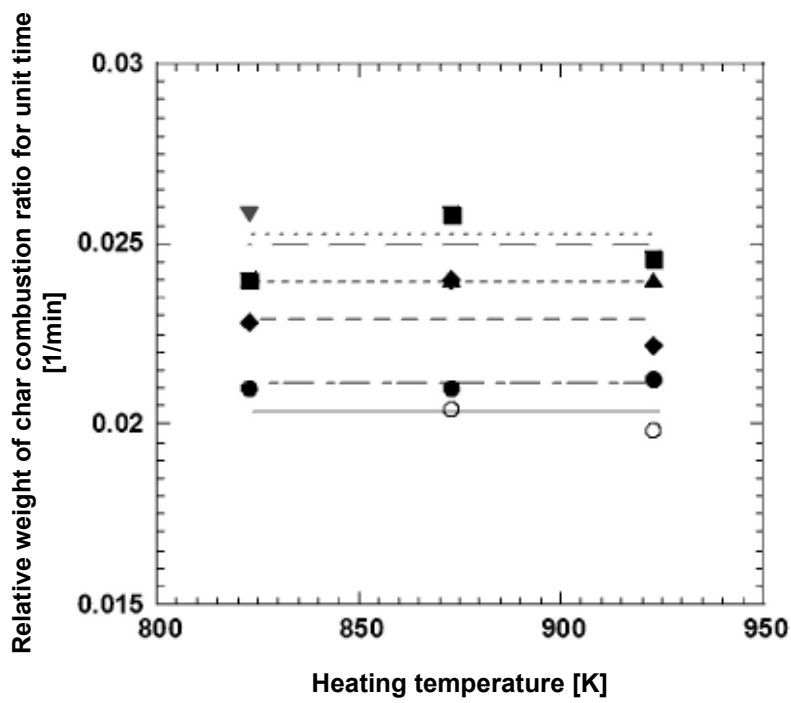

Fig.13 Relative weight of char combustion ratio for unit time in different heating temperature: Raw material $(\bigcirc)$, BIC powder ( ), T- BIC powder $(\mathrm{Tb}=523 \mathrm{~K})(\nabla)$, T- BIC powder $(\mathrm{Tb}=573$ $\mathrm{K})(\boldsymbol{\Delta})$, T- BIC powder $(\mathrm{Tb}=623 \mathrm{~K})(\boldsymbol{\nabla})$, T- BIC powder $(\mathrm{Tb}=673 \mathrm{~K})(\mathbf{\square})$.

T-BIC powder の試料中に含まれる揮発成分 $1 \mathrm{~g}$ がガス化に 要する時間 $\mathrm{t}_{\mathrm{g}}$ と揮発成分率 $\mathrm{W}_{\mathrm{v}}$ の相関を示す。 $\mathrm{t}_{\mathrm{g}}$ は、次式 で表される。ここで、G は試料重量 $[\mathrm{g}]$ である。

$$
\mathrm{t}_{\mathrm{g}}=\mathrm{t}_{\mathrm{v}} / \mathrm{GW}_{\mathrm{v}}
$$

$\mathrm{W}_{\mathrm{v}}$ が約 $45 \%$ の付近で傾向が異なり、 $\mathrm{W}_{\mathrm{v}}$ が約 $45 \%$ 以下 の T-BIC powder は $\mathrm{t}_{\mathrm{g}}$ と $\mathrm{W}_{\mathrm{v}}$ は負の相関関係にあり、直線的 に近似出来、 $\mathrm{W}_{\mathrm{v}}$ が約 $45 \%$ 以上の T-BIC powder および原料、 


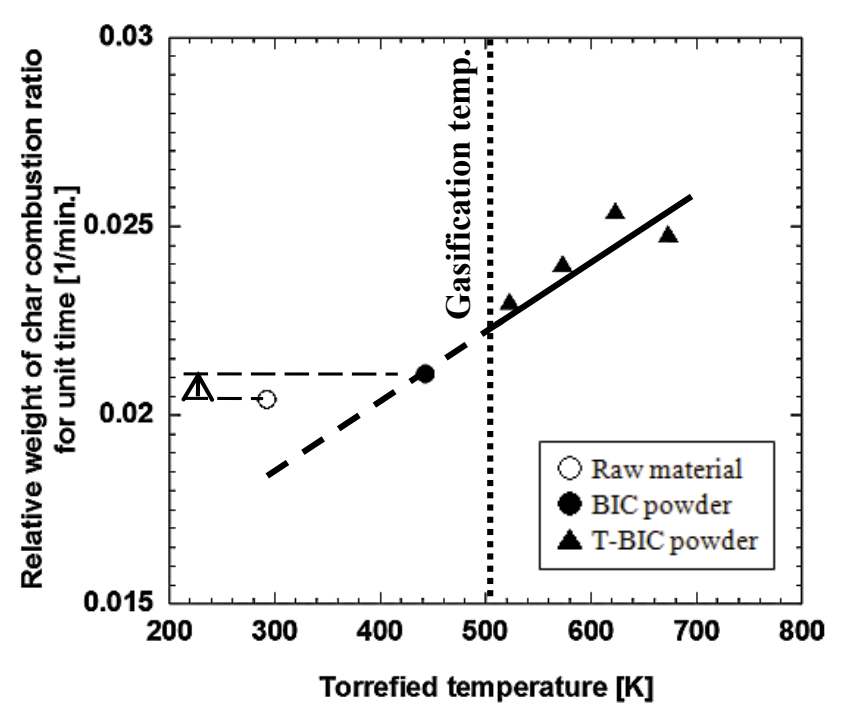

Fig.14 Relative weight of char combustion ratio for unit time in different torrefied temperature.

BIC powderでは Tcに関わらず、 $\mathrm{t}_{\mathrm{g}}$ が一定值となり、下限 值があることがわかる。

最後に、固定炭素燃焼域に着目し、試料投入後、約 300 〜 900 秒間の Tcに対する単位時間当たりの相対重量チャー 燃焼率 $\gamma_{\mathrm{c}}$ をFig.13に示す。チャー燃焼は Tc に関わらず、 一定の速度で然焼が進行していることがわかる。Fig.14 に $\mathrm{Tb}$ と $\gamma_{\mathrm{c}}$ の相関を示す。Fig.10 と同様に原料は常温 293 K、BIC powder は BIC 成型温度 $443 \mathrm{~K}$ で、プロットした。 T-BIC powder は、Tb が高くなるにつれ、 $\gamma_{\mathrm{c}}$ が増加すること がわかる。BIC powder は T-BIC powderの近似線の延長線上 にあり、原料と比較すると、若干ではあるが、 $\gamma_{\mathrm{c}}$ が増加し ていることがわかる。Fig.15に原料、BIC powder、T-BIC powderの試料中に含まれる固定炭素 $1 \mathrm{~g}$ 当たりのチャー燃 焼時間 $\mathrm{t}_{\mathrm{d}}$ と固定炭素率 $\mathrm{W}_{\mathrm{c}}$ の相関図を示す。 $\mathrm{t}_{\mathrm{d}}$ は、次式で 表される。

$$
\mathrm{t}_{\mathrm{d}}=\mathrm{t}_{\mathrm{c}} / \mathrm{GW}_{\mathrm{c}}
$$

$\mathrm{W}_{\mathrm{c}}$ が約 $50 \%$ 付近で傾向が異なり、 $\mathrm{W}_{\mathrm{c}}$ が約 $50 \%$ 以下の 原料、BIC powder、T-BIC powder では $\mathrm{t}_{\mathrm{d}}$ が一定值を取り、 上限值があることがわかった。 $\mathrm{W}_{\mathrm{c}}$ が約 $50 \%$ 以上の T-BIC powderでは $\mathrm{W}_{\mathrm{c}}$ の増加に従い、祙 は短縮されることがわかる。

\section{4. 結 論}

本研究では、トレファイド・バイオコークス (T-BIC) の 作製および熱分析、トレファイド・バイオコークスの粉砕 物 (T-BIC powder) の燃焼実験結果から次のことを得た。

1) トレファクション処理を行った場合の重量収率は、トレ ファクション温度 $\mathrm{Tb}$ と負の相関関係があり、 $\mathrm{Tb}=673$

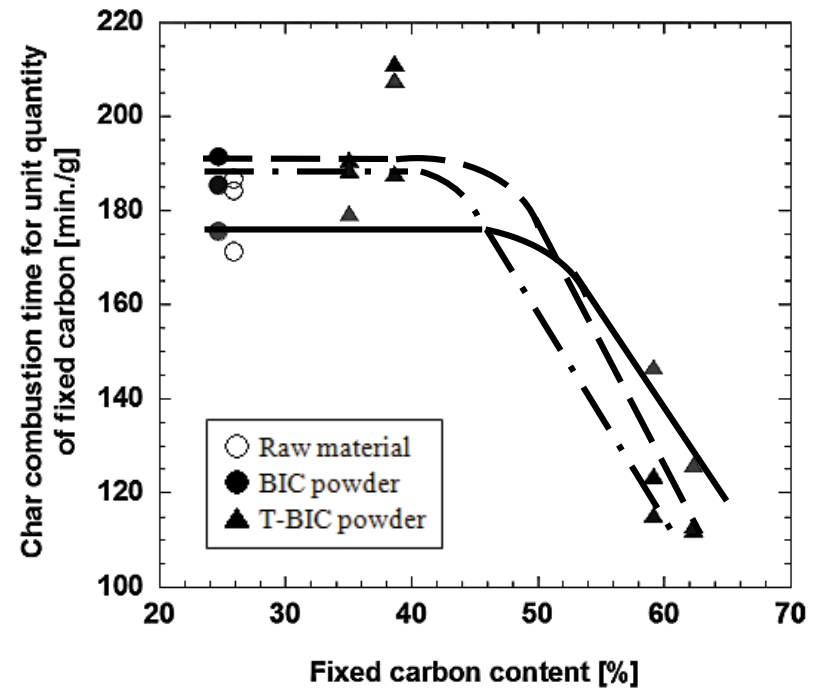

Fig.15 Char combustion time for fixed carbon content: Broken line: $\mathrm{Tc}=823 \mathrm{~K}$, Chain line: $\mathrm{Tc}=873 \mathrm{~K}$, Solid line $: \mathrm{Tc}=923 \mathrm{~K}$.

$\mathrm{K}$ 以上で一定值に収束する。

2) トレファイド・バイオコークス (T-BIC) に含まれる揮発 性物質と固定炭素の重量率は、トレファクション温度 $\mathrm{Tb}$ に依存し、 $\mathrm{Tb}$ が高いほど、固定炭素率は高くなり、 エネルギー密度を高めることが出来る。緑茶の場合、卜 レファクション処理により、固定炭素率を $25 \%$ から 62 \%に高めることができる。

3) トレファイド・バイオコークスの粉砕物 (T-BIC powder) の揮発成分のガス化特性は、揮発成分の含有率が約 45 $\%$ で傾向が遷移する。約 $45 \%$ 以下では揮発成分の含有 率が低いほど、単位重量当たりのガス化時間は延長され、 約 $45 \%$ 以上では、一定值となり、下限值があることが わかった。

4) トレファイド・バイオコークスの粉砕物 (T-BIC powder) のチャー燃焼特性は、固定炭素の含有率約 $50 \%$ で傾向 が遷移する。約 $50 \%$ 以下では、一定值となり、上限值 があることがわかった。また、約 $50 \%$ 以上では、固定 炭素の含有率が高いほど、チャー燃焼時間は短縮される。

\section{謝 辞}

本研究の一部は、近畿大学理工学部機械工学科・中川雄 太君の卒業研究ノートと実験協力により、得られた成果で あり、ここに記し、謝意を表する。

\section{参考文献}

1) 丹野賢二、牧野尚夫：燃料多様化と負荷追従性に優れた微粉 炭燃焼技術の開発、スマートプロセス学会誌 4-1 (2015) 20-24.

2) Satoru MIZUNO, Tamio IDA, Manabu FUCHIHATA and Kunihiko 
NAMBA, Effect of specimen size on ultimate compressive strength of Bio-coke produced from green tea grounds, Mechanical Engineering Journal 3-1 (2016) 15-00441.

3) 井田民男、高木亮伍、水野諭、サンチエスエドムンド、難波邦彦: 緑茶を原料とする高密度バイオ固体燃焼の形成条件による物 理的特性に関する研究、スマートプロセス学会誌 2-2 (2013) 83-87.

4) 水野諭、井田民男、㴊端学、難波邦彦、加子坂篤志、藤田修: 草本系バイオマスを原料とする高密度 ·高硬度固形物の成型 特性、Journal of the Japan Institute of Energy 91-1 (2012) 41-47.

5) 川見佳正、桑名一徳、井田民男、水野諭、森田明宏 : 茶㳯等 を $180{ }^{\circ} \mathrm{C}-20 \mathrm{MPa}$ 条件で高密度固形燃料化する技術開発、高 温学会誌 35- 2 (2009) 97-101.

6) 佐野寛、本庄孝子：バイオマス半炭化の原理と効用、高温学 会誌 37-2 (2011) 43-49.

7) 石村健志、井田民男、㴊端学、本庄孝子、佐野寛 : 半炭化固 形化技術による木質系バイオマスの熱エネルギー特性の向上、 高温学会誌 33-1 (2007) 38-42.
8) 本荘孝子、井田民男、㴊端学、佐野寛：新燃料 BCDF の可 能性一七ルロース半炭化ペレットのエネルギー密度・エネル ギー収率の最適化を求めて一、Journal of the Japan Institute of Energy 84-2 (2005) 142-148.

9) 赤藤雄也、足立佑平、田付圭祐、㴊端学、井田民男：高硬度 バイオマス燃焼の炭化および燃焼挙動、スマートプロセス学 会誌 3-5 (2014) 269-275.

10) 内山ら：高温ガス直接溶融炉におけるバイオコークス使用に よる $\mathrm{CO}_{2}$ 排出量削減、日本機械学会論文集 (B 編) 78-789 (2012) 61-64.

11) 石井一義、村田博敏、桑名一徳、水野諭、村田明宏、井田民男: 茶滓を原料とするバイオコークスによる溶解炉内管観察と燃 焼シミュレーション、高温学会誌 35-2 (2009) 91-96.

12) 水野諭、森田明宏、井田民男、難波邦彦、㴊端学、澤井徹 : 多様なバイオマス資源の組成・熱分解分析から抽出した特性 とその相関、高温学会誌 34-4 (2008) 153-159.

13）森田明宏：木質バイオマスのガス化過程における基礎熱分解 特性とその予測手法の検討、高温学会誌 35-2 (2009) 85-90. 